\title{
ІСТОРИЧНІ ПЕРЕДУМОВИ ТА ПРИЧИНИ РОСІЙСЬКО-ГРУЗИНСЬКОЇ ВІЙНИ 2008 РОКУ
}

\begin{abstract}
Анотація: У статті висвітлено історичні передумови та причини війни між Російською Федерацією та Грузією 2008 року. Витоки конфлікту між урядом Грузї та регіональною владою Південної Осетії та Абхазії простежуються внаслідок розпаду Радянського Союзу в 1991 році та наступних громадянських воєн. 3 часу припинення вогню на початку 1990-х років Росія виступала гарантом фактичної автономії як Південної Осетії, так і Абхазії. Військове протистояння між Росією та Грузією мало значний вплив на політичний $і$ стратегічний світогляд Грузї та безпосередньо на регіон. У статті зроблено спробу визначити й охарактеризувати історичні передумови та причини російсько-грузинської війни 2008 року.
\end{abstract}

Ключові слова: Грузія, Російська Федерація, Південна Осетія, Абхазія, війна, конфлікт

Російська Федерація традиційно вважає Південний Кавказ сферою своїх привілейованих інтересів і конкурує за сфери впливу із Заходом (на чолі зі США) та регіональним актором - Туреччиною. Країни Південного Кавказу в своїй геополітиці змушені спиратися на допомогу зовнішніх союзників (партнерів). у субрегіоні існує геополітичне протистояння між Росією та Заходом, котрий підтримує Грузію як свій «форпост» на Південному Кавказі. Стратегія Росії передбачає збереження контролю над своїми сателітами - Південною Осетією й Абхазією та можливе використання їх в якості геополітичних «плацдармів». Аналіз історичних передумов і причин війни між Росією та Грузією у 2008 р. розкриває загальну стратегію поведінки РФ на міжнародній арені загалом та на пострадянському просторі зокрема. З'ясування передумов і причин російськогрузинської війни 2008 р. є актуальним і через схожість із ситуацією, що склалась в Україні.

Історичні передумови та причини російсько-грузинської війни 2008 р. вивчали багато дослідників. Зокрема, слід виокремити праці М. Кофмана, О. Алєксєйченко, Б. Кушнірука ${ }^{3}$ В. Мартинюка ${ }^{4}$, Г. Соловій5 та інших. У статті не використовувались роботи

\footnotetext{
"Габро Ірина Володимирівна - кандидат політичних наук, доцент кафедри міжнародних відносин та зовнішньої політики Чорноморського національного університету імені Петра Могили (Миколаїв, Україна); ORCID: https://orcid.org/0000-0001-8215-7615; e-mail: irngabro@gmail.com

Куріленко Аліна Вікторівна - магістр міжнародних відносин Чорноморського національного університету імені Петра Могили (Миколаїв, Україна);

ORCID: https://orcid.org/0000-0001-9307-2879; e-mail: alina29ku@ukr.net

${ }^{1}$ Kofman M. The august war, ten years on: a retrospective on the russo-georgian war / War on the rocks. URL: https://warontherocks.com/2018/08/the-august-war-ten-years-on-a-retrospective-on-the-russo-georgian-war/

${ }^{2}$ Алєксєйченко О.В. Етнополітичні конфлікти в регіоні Південного Кавказу: історико-політичні передумови // Актуальні проблеми міжнародних відносин. 2013. Вип. 116 (Частина I). С. 61-69.

${ }^{3}$ Кушнірук Б. Як насправді розпочиналася російсько-грузинська війна / Уніан. URL: https://www.unian.ua/politics/138744-yak-naspravdi-rozpochinalasya-rosiysko-gruzinska-viyna.html
} 
російських авторів через необ’єктивність висвітлення причини війни 2008 року.

Серпень 2008 р. сколихнув світову спільноту новими проявами агресії на постколоніальних просторах колишнього СРСР і новим витком протистояння на Кавказі, де вже багато років не знаходить свого вирішення заморожений грузино-осетино-абхазькоросійський конфлікт. Якщо поглянемо в корінь та історію даного питання, то побачимо, що витоки конфлікту сягають часів розпаду СРСР та появи нових незалежних держав, котрі змушені були самотужки з'ясовувати стосунки з національними меншинами на своїй території.

Причини війни по-різному оцінюються у дослідженнях, відображаючи геополітичні наміри акторів, що були задіяні. Була створена Міжнародна слідча комісія під керівництвом швейцарського дипломата Х. Тальявіні («Комісія Тальявіні»), яка працювала під егідою ЄС, зі встановлення фактів і дослідження витоків і ходу конфлікту у Грузії відповідно до міжнародного права (включаючи Гельсінський Заключний акт), гуманітарного права та прав людини. Відповідно до результатів розслідування, представлених у формі доповіді, Грузія розв'язала війну, а Росія на це її спровокувала. Також голова комісії Х. Тальявіні висловила тезу про «непропорційність» використання сили під час конфлікту російською стороною ${ }^{7}$.

Грузино-осетино-абхазький конфлікт став ще у 1990-х роках одним з найгостріших етнополітичних конфліктів, які потребували дуже обачного та дипломатичного підходу 3 усіх сторін, задіяних у протистояння. Першопричинами грузино-абхазького конфлікту стала міграційна політика, котра проводилась Берією і призвела до зменшення чисельності абхазців на території регіону, де станом на 1990-ті роки абхазців було близько 17\%, а решта грузини та вірмени. До 1950-років абхазька мова не викладалась у школі і була замінена грузинською. Згодом на території Абхазії у 1957, 1967, 1978 роках лунали заклики до виходу з Грузинської РСР, котрі вилились у загострення взаємин у березні 1989 р., коли 30тисячний Схід абхазького народу озвучив відновлення союзного статусу Абхазії та її вихід зі складу Грузії.

Як відзначає О.Алєксєйченко, Абхазію Грузія фактично втратила ще в 1992 р. не в останню чергу тому, що абхазці, маючи досить умовну (за радянських часів) автономію, зберегли національну ідентичність і значною мірою «націоналізовані» місцеві владні структури. Більшість ключових посад в адміністрації Абхазької АРСР посідали етнічні абхазці і саме вони на хвилі національного відродження поставили питання про отримання Абхазією статусу союзної республіки. У цьому вони отримали вагому підтримку з Москви, яка побоювалася виходу Грузії, фактичним очільником якої став колишній дисидент, голова Верховної ради Грузинської РСР Звіад Гамсахурдіа, зі складу СРСР. Сприяло унезалежненню Абхазії від Грузії і зближення абхазьких лідерів з керівництвом підрозділів Збройних сил СРСР, дислокованих в автономії, втручання яких у грузинсько-абхазький

\footnotetext{
${ }^{4}$ Мартинюк B. Російсько-грузинський конфлікт: зміна тенденцій поставок енергоносіїв 3 Каспійського регіону / Українська правда. URL: http: www.pravda.com.ua/news/2008/9/19/81534.htm.

${ }^{5}$ Соловій Г. Грузино-російська війна на Кавказі: історія, причини і наслідки // Науковий часопис НПУ імені М.П. Драгоманова. 2009. Вип. 1. С. 101-105.

${ }^{6}$ Ibid. C. 101.

${ }^{7}$ Алєксєйченко О.В. Етнополітичні конфлікти в регіоні Південного Кавказу... С. 67.
} 
конфлікт на боці останніх стало вирішальним чинником у військовій перемозі Абхазії

Скасування 21 лютого 1992 р. Конституції Грузинської РСР та відновлення попередньої Конституції Грузинської демократичної республіки 1921 р. абхазьке керівництво сприйняло як відміну автономного статусу Абхазії. Саме через це абхазьке керівництво одноосібно відновило власну Абхазьку конституцію, за якою країна визнавалась суверенною. Втім, міжнародна спільнота не визнала такого самочинства. Почався новий виток і загострення протистояння, що змусило Тбілісі ввести війська в автономію.

14 серпня 1992 р. між Грузією та Абхазією почалися військові дії, які переросли у справжню війну із застосуванням авіації, артилерії й інших видів зброї. Метою грузинського уряду було встановлення контролю над частиною своєї території і збереження іiї цілісності. Метою абхазьких властей - розширення прав автономії i, зрештою, отримання незалежності. Політичну та матеріальну підтримку абхазькій стороні надавала Росія під керівництвом Б. Єльцина, яка допомогла тимчасово згладити протистояння. На боці абхазьких збройних формувань виступали також представники бунтівної Чечні, так зокрема, коли 27 вересня 1993 р. Сухумі був узятий абхазькими та північнокавказькими загонами, у складі останніх бойовий досвід отримали чеченські керівники, зокрема Шаміль Басаєв 9 .

Російська сторона у 1990-х роках формально намагалася зберігати нейтральний статус, хоча їі збройні формування, які залишились ще 3 радянських часів, таки були звинувачені Тбілісі у веденні розвідувальних операцій. 2 квітня 2002 р. був підписаний грузино-абхазький протокол, згідно з яким патрулювання верхньої частини Кодорської ущелини (територія Абхазії, контрольована Грузією) було доручене російським миротворџям і військовим спостерігачам ООН. 18 жовтня 2006 р. Народне зібрання Абхазії звернулося до російського керівництва 3 проханням визнати незалежність республіки. Зі свого боку російське керівництво у той час неодноразово заявляло про безумовне визнання територіальної цілісності Грузії, невідємною частиною якої є Абхазія.

Щодо історії грузино-осетинського конфлікту, то його витоки теж ідуть 3 1990-х років, коли наприкінці 1989 р. рада народних депутатів Південно-Осетинської автономної області ГРСР прийняла рішення про підвищення статусу автономії до республіканського у межах Грузинської РСР і надання осетинській мові статусу державної на території Південної Осетії. У відповідь на такі дії Президія Верховної Ради Грузії відмінила рішення осетинської обласної ради, як неконституційне, що вилилось у похід на Цхінвалі 30-40 тис. грузинських мітингувальників на чолі з Головою Хельсінкської групи Грузії Звіадом Гамсахурдія ${ }^{10}$.

Осетинська влада здійснила низку провокативних дій, приймаючи декларацію «Про суверенітет Південної Осетії», все це грузинська сторона визнала протизаконним і такими, що суперечать чинній конституції. У грудні 1990 р. сесія Верховної Ради Грузії прийняла рішення про скасування автономної області. І знову посередником у конфлікті стала Росія,

\footnotetext{
${ }^{8}$ Алєксєйченко О.В. Етнополітичні конфлікти в регіоні Південного Кавказу... С. 67.

${ }^{9}$ Соловій Г. Грузино-російська війна на Кавказі... С. 102.

${ }^{10}$ Кушнірук Б. Російсько-грузинська війна: причини та наслідки // УНIAH. 2008. 18 серпня. URL: http://www.unian.net/ukr/news/news-267814.html.
} 
у 1991 р. президент СРСР М.Горбачов відмінив рішення осетинської облради про проголошення Південно-Осетинської Республіки і рішення Верховної Ради Грузії про скасування ПОАО, як такі, що не відповідають Конституції Радянського Союзу, та зобов’язав керівництво МВС ГРСР вивести свої підрозділи з території Південної Осетії. У той же день відбувається збройне зіткнення між мешканцями Цхінвалі та грузинськими міліціонерами. 3 цієї дати грузино-осетинський конфлікт переходить у збройну фазу ${ }^{11}$.

у липні 1992 р. на підставі Дагомиських грузино-російських домовленостей 3 врегулювання грузино-осетинського конфлікту у зону конфлікту був введений військовий контингент миротворчих сил РФ. Миротворчі сили у Південній Осетії називались змішаними, натомість до них входили винятково російські військові підрозділи. Відомі також факти, що Національна гвардія та озброєні групи в Осетії та Абхазії були створені силовими структурами Росії, передусім ФСБ. Зброю військовим формуванням на території обох автономій постачала також російська сторона ${ }^{12}$.

Конфлікти в Абхазії та Південній Осетії залишалися в основному замороженими до 2003 р., коли безкровна Революція троянд у Грузії не врегулювала статус-кво. Міхеїл Саакашвілі став президентом у січні 2004 p., і він відразу визначив пріоритетом повернення всіх відколотих регіонів, включаючи Абхазію та Південну Осетію, а також Аджарію. На відміну від інших двох анклавів, сформованих війною, Аджарія була приватною феодальною власністю Аслана Абашидзе $\mathrm{e}^{13}$.

у 2004 р. Грузія з легкістю повернула Аджарію. Абашидзе подав у відставку та виїхав у заслання до Росії. Примусова дипломатія Саакашвілі спрацювала, і цей успіх його надихнув. Потім він почав чинити тиск на Південну Осетію, ремілітаризував заморожений конфлікт, наказавши силам MBC і поліції увійти в регіон, офіційно «боротися 3 контрабандистами, що діють з Росіі». Боротьба спалахнула між грузинськими військами й осетинами навколо Цхінвалі, але грузинські військові виявили, що не в змозі взяти область силою. У серпні 2004 р., в одному з найстрашніших боїв того року, війська МВС Грузії захопили стратегічну висоту навколо обїзної дороги, але згодом відійшли. Саакашвілі розпочав трансформаційну програму з розширення, модернізації та озброєння грузинських військових, щоб змінити військовий баланс на користь Грузії. Грузинські військові витрати різко зросли з 2004 по 2008 рік - з 74 мільйонів доларів у 2003 р. до 876 млн. доларів у $2008 \mathrm{p}$.

На початок російсько-грузинського протистояння у 2008 р. територіями автономій керували переважно вихідці і громадяни Російської Федерації, зокрема колишній службовець КДБ Анатолій Баранов, що раніше очолював ФСБ Мордовії, начальник МВС Михайло Міндзаєв - апарат МВС Північної Осетії, міністр оборони Василь Луньов був військовим комісаром російського міста Перм, а секретар Ради Безпеки Анатолій Баранкевич - у минулому заступник комісара Ставропольського краюю ${ }^{14}$.

\footnotetext{
${ }^{11}$ Кушнірук Б. Як насправді розпочиналася російсько-грузинська війна...

${ }^{12}$ Манжола В. Проект будівництва Великої Європи // UA Foreing Affairs. 2009. №2. URL: http://uaforeignaffairs.com/article.html/print?id=326

${ }^{13}$ Kofman $M$. The august war...

${ }^{14}$ Мартинюк В. Російсько-грузинський конфлікт: зміна тенденцій поставок енергоносіїв 3 Каспійського регіону // Українська правда. 2008. 19 вересня. URL: http: www.pravda.com.ua/news/2008/9/19/81534.htm
} 
Як відзначає американський дослідник М. Кофман, у 2008 р. відбулися важливі каталізуючі події - визнання незалежності Косово Сполученими Штатами та більшістю держав ЄС, а також саміт НАТО в Бухаресті у 2008 р., коли Альянс пообіџяв, що Україна та Грузія стануть членами НАТО. Для Москви обидва ці рішення перетнули червоні лінії. До 2008 р. РФ розробила плани військової операції 3 нав'язування своєї волі Грузії. Стратегічною метою було надати Москві правдоподібне заперечення, коли мова заходила про те, кого винуватити у конфлікті, водночас перешкоджаючи Грузії мати можливість вибрати власний стратегічний напрямок. Москва активно шукала війни і сподівалася, що вона може призвести до зміни режиму в Тбілісі ${ }^{15}$.

Цікавою є думка М. Кофмана про те, що Росія підготувала лідера Грузії М. Саакашвілі до початку бойових дій проти своїх довірених сил у Південній Осетії, а потім розгромила грузинські військові у короткому звичайному конфлікті. Саакашвілі пішов цим шляхом, незважаючи на попередження США, через власні амбіції. Проте Москва також була здивована часом нападу Грузії, який дещо випереджав російські плани. Декларація НАТО додала ширший геостратегічний вимір війні, яка вже йшла по шляху, враховуючи амбіції Грузії повернути втрачену територію та намір Росії нанести Саакашвілі велику поразку. Путін не збирався дозволяти Саакашвілі повернути території назад, але після декларації НАТО на Бухарестському саміті він вирішив дати Заходу урок про здатність Росії ветувати подалыше розширення НАТО на схід.

Наприкінці квітня 2008 р. над Абхазією був збитий безпілотний літак-розвідник, що залетів 3 території Грузії. Цей інцидент викликав серйозний міжнародний скандал. Грузія обвинуватила Росію у тому, що її військово-повітряні сили збили літак, а також зажадала розгляду ситуації в Раді Безпеки ООН. Тим часом РБ ООН не прийшла до єдиної думки із приводу ситуації в Абхазії. 3 обох питань - про зміцнення зв'язків Росії й невизнаних республік і про політ грузинського безпілотного літального апарата - члени Ради лише заслухали думку Росії. Після цих подій, ситуація у зоні грузино-абхазького конфлікту різко загострилася. Москва ввела в Абхазію додаткові сили миротворців. А Тбілісі розцінив цей крок як військову агресію.

До кінця травня 2008 р. російські залізничні війська були направлені на ремонт залізничних сполучень з Абхазією, що дозволило б широкомасштабним силам надходити в сепаратистський анклав у разі конфлікту. Це було досить яскравим показником підготовки Росії до швидкого переміщення великої кількості сил у разі воєнних дій з Грузією. Обміни гарматними вогнями та епізодичні атаки значно посилилися в місяці, що передували початку війни. Але основна увага зосереджувалась на Абхазії як на вірогідній точці конфлікту, доки події не загострилися у Південній Осетії.

3 липня 2008 р. в результаті бомби загинув керівник осетинської міліції. Відразу після замаху на життя Санакоєва загинуло кілька грузинських солдатів спецназу. Південна Осетія оголосила загальну мобілізацію, оскільки грузинські війська захопили стратегічне гірське розташування. Російські винищувачі також здійснили обліт повітряного простору Осетії напередодні візиту Кондолізи Райс до Грузії. Росія та США розпочали окремі військові навчання в регіоні у липні 2008 р. Російські військові навчання «Кавказькі

${ }^{15}$ Kofman $M$. The august war... 
кордони 2008» готували частини до конфлікту з Грузією. Спільні навчання США з Грузією «Негайна відповідь 2008» мали досить іронічну назву, з огляду на наступні події ${ }^{16}$

Абхазьке керівництво вирішило скористатись війною у Південній Осетії у серпні 2008 р. для остаточного виходу 3-під юрисдикції офіційного Тбілісі і міжнародного визнання своєї державності ${ }^{17}$.

Визнавши незалежність самопроголошених республік, Москва твердить, що тепер вони мають право розташовувати свої військові формування, погоджуючи це лише 3 обраним керівництвом Абхазії й Осетії ${ }^{18}$.

Загалом абсурдним виглядає сам факт того, що РФ як агресор, будучи задіяною і зацікавленою у даному протистоянні, виступає посередником. I тут світова спільнота ще у 1990-х роках допустила величезну помилку, дозволивши Росії одноосібно виступати в ролі так званого миротворця, хоча 2 квітня 2002 р. був підписаний грузино-абхазький протокол, згідно з яким патрулювання верхньої частини Кодорської ущелини було доручено не лише росіянам, але й військовим спостерігачам $\mathrm{OOH}$.

Якщо порівняти грузино-російський конфлікт щодо Південної Осетії та Абхазії 3 аналогічними етнічними конфліктами у Косово та Чечні, то непослідовність позиції Росії очевидна. Анексуючи автономії, які були у складі Грузії, Росія заперечує територіальну цілісність незалежної суверенної держави, однак, коли у Сербії забирали Косово, Росія була на стороні Белграда. Тут власне непослідовність проявили і міжнародні структури, зокрема ООН, мотивуючи це морально-політичною доцільністю. Європа сама створила прецедент, зафіксувавши таким чином перехід до міжнародного права, заснованого на силі та власних інтересах. Цікавий також інший момент, що коли Чечня вимагала незалежності, російська влада затаврувала її ярликом «чеченські терористи», а коли ті ж чеченці виступали на боці абхазців і осетин, - то російська сторона теж стала на сторону сепаратистів, переслідуючи свої власні цілі. Отже, як бачимо, аргументація російської сторони настільки суперечлива і мінлива, що вести переговори з Росією справа невдячна і нерідко заздалегідь приречена ${ }^{19}$.

Отже, зусилля Росії розділити європейські нації та нехтування територіальною цілісністю почалися не 3 конфлікту в Україні. Швидше, це почалося 3 розчленування Молдови у 1990-х рр. і воєн та окупації Абхазії та Південної Осетії в Грузії. Україна - лише остання держава, яка стала жертвою агресивного курсу Кремля, і ми можемо лише припускати, хто буде наступним. У 2008 р. росіяни мали намір усунути режим Саакашвілі і взяти Тбілісі. Вони не змогли цього зробити, оскільки в Тбілісі зібралися лідери Полыщі, країн Балтії та України, а також тому, що європейці та США підштовхнули Москву зупинити агресію.

\footnotetext{
${ }^{16}$ Kofman $M$. The august war...

${ }^{17}$ Алєксєйченко О.В. Етнополітичні конфлікти в регіоні Південного Кавказу... С. 68.

${ }^{18}$ Пасова Т. Новий кавказький трикутник: Москва - Тбілісі - Страсбург // Віче. 2008. № 19. С. 11.

${ }^{19}$ Рахманін С. Якщо завтра війна? // Дзеркало тижня. 2008. № 31 (710). 23-29 серпня. С. 1-2.
} 


\section{Historical background and causes of the Russian-Georgian War of 2008}

Abstract: The Russian Federation traditionally considers the South Caucasus an area of its privileged interests and competes for spheres of influence with the West (led by the United States) and a regional actor, Turkey. The countries of the South Caucasus in their geopolitics are forced to rely on the help of external allies (partners). In the subregion, there is a geopolitical confrontation between Russia and the West, which supports Georgia as its «outpost» in the South Caucasus. Russia's strategy calls for maintaining control of its satellites in South Ossetia and Abkhazia and their possible use as geopolitical «bridgeheads». An analysis of the historical background and causes of the war between Russia and Georgia in 2008 reveals the general strategy of Russia's behavior in the international arena in general and in the postSoviet space in particular.

The article highlights the historical background and causes of the war between the Russian Federation and Georgia in 2008. The origins of the conflict between the Georgian government and the regional authorities of South Ossetia and Abkhazia can be traced back to the collapse of the Soviet Union in 1991 and subsequent civil wars. Since the ceasefire in the early 1990s, Russia has been the guarantor of de facto autonomy for both South Ossetia and Abkhazia. The military confrontation between Russia and Georgia has had a significant impact on Georgia's political and strategic worldview and on the immediate region. The article attempts to identify and characterize the historical background and causes of the RussianGeorgian war of 2008.

Russia's efforts to divide European nations and its neglect of territorial integrity did not begin with the conflict in Ukraine. Rather, it began with the dismemberment of Moldova in the 1990s and the wars and occupation of Abkhazia and South Ossetia in Georgia. Ukraine is only the last country to fall victim to the Kremlin's aggressive course, and we can only guess who will be next. In 2008, the Russians intended to overthrow Saakashvili's regime and take Tbilisi. They failed to do so because the leaders of Poland, the Baltic states and Ukraine gathered in Tbilisi, and because Europeans and the United States pushed Moscow to stop the aggression.

Keywords: Georgia, Russian Federation, South Ossetia, Abkhazia, war, conflict 